\title{
Assessment of Micro-Shear Bond Strength of a Self-Etch Adhesive System to Enamel
}

\author{
Basma Hosny ${ }^{*}$ Emad Abdel-Fattah, Mohsen Abi El Hassan \\ Department of Operative Dentistry, Faculty of Dentistry, Suez Canal University, Egypt
}

\begin{abstract}
Aim: the aim of this study was to evaluate the micro-shear bond strength of three bonding approaches to enamel namely, two-step etch and rinse bonding approach, one step self-etch bonding approach, and one step self-etch bonding approach with pre-etching. Materials and Methods: Ninety sound human permanent molars were used in this study. The teeth were divided into three main groups according to the type of bonding approaches $(n=30)$. The teeth were embedded in acrylic block, the buccal surface was grounded to expose flat enamel and to receive two composite rods. Specimens were kept in distilled water $\left(37^{\circ} \mathrm{C}\right.$ for $\left.24 \mathrm{~h}\right)$, and submitted to micro-shear testing. Results: The micro-shear bond strength of the etch and rinse bonding approach was the highest whereas the self-etch bonding approach was the lowest and there was a significant difference between the three groups. Conclusions: Etch and rinse-bonding approach is the most predictable technique for bonding of resin composite to enamel, Pre- etching step of enamel plays a positive critical role in improving the bond strength of self-etch bonding approach to enamel.
\end{abstract}

Keywords: rinse, bonding, resin

\section{Introduction}

Etch and rinse adhesives involve a separate etch-and-rinse phase, as this technique requires conditioning, rinsing, and drying steps prior to adhesive application. Clinical success with these bonding systems is thought to be technique- sensitive and materials related as well as time consuming ${ }^{(1)}$. The technique sensitivity associated with the use of etch and rinse adhesive systems pushed the research work for production of different adhesive systems, the so called self-etch adhesive system which is based on the use of non-rinse acidic monomers that simultaneously condition and prime dentin and enamel ${ }^{(2)}$. However, this system was advocated only to be applied on dentin alone, therefore required clin ically selective-enamel etching in a separate step because their ability to etch enamel is less than phosphoric acid. Most studies found that the bond strengths of composite to enamel provided with these self-etching adhesive systems are significantly lower when compared to etch-and-rinse adhesive systems $^{(3)}$.

\section{Material and Methods}

The teeth were divided into three groups ( 30 teeth each) according to type of bonding approaches: etch and rinse approach (1), selfetch approach (2), and self-etch with pre etching (3). A split mould was used to prepare acrylic block for tooth holding, the buccal surface of each tooth was grounded 
with silicon carbide paper up to 600 grits to this study (table 1 ). They were stored in norexpose flat enamel and create uniform smear mal saline at room temperature and were layer. Two types of adhesive systems and used within one month following extraction. one resin composite material were used in

Table 1: Materials used and their composition

\begin{tabular}{|l|l|l|}
\hline Material & Specification & Composition \\
\hline $\begin{array}{l}\text { Adper }{ }^{\text {MM }} \text { Single Bond2 } \\
\text { Adhesive }\end{array}$ & $\begin{array}{l}\text { Two-step etch \& } \\
\text { rinse adhesive } \\
\text { system }\end{array}$ & $\begin{array}{l}\text { Etchant: silica-thickened 35\% phosphoric acid gel } \\
\text { Adhesive: Bis-GMA, HEMA, Copolymer of acrylic and } \\
\text { itaconic acids, Water, Ethanol, 1,3-dimethacrylate, } \\
\text { diurethanedimethacrylate, Silane treated silica and } \\
\text { glycerol. }\end{array}$ \\
\hline $\begin{array}{l}\text { Single Bond Universal } \\
\text { Adhesive }\end{array}$ & $\begin{array}{l}\text { One-step self } \\
\text { etch adhesive } \\
\text { system }\end{array}$ & $\begin{array}{l}\text { MDP Phosphate Monomer, Dimethacrylate resins, } \\
\text { HEMA, Vitrebond } \\
\text { tiators Copolymer, Water, Ethanol, Ini- }\end{array}$ \\
\hline $\begin{array}{l}\text { Filtek }{ }^{\text {TM }} \text { Z250 (shade } \\
\text { A3) }\end{array}$ & $\begin{array}{l}\text { Micro-hybrid } \\
\text { light cured } \\
\text { composite resin }\end{array}$ & $\begin{array}{l}\text { Resin: BIS-GMA, TEGDMA. } \\
\text { Filler: Zirconium and Silica } \\
\text { The inorganic filler loading is 60\% by volume "with- } \\
\text { out silane treatment" with particle size range of } \\
\text { o.01 and 3.5 microns. } \\
\text { Additional contents: stabilizers, catalysts, and pig- } \\
\text { ments. }\end{array}$ \\
\hline
\end{tabular}

Table 2: Descriptive statistics and test of significance for the effect of adhesive system on micro-shear bond strength in (MPa) to enamel

\begin{tabular}{|l|llll|}
\hline Application of adhesive system & Mean & SD & Min. & Max. \\
\hline Two-step etch and rinse adhesive (1) & 31.307 & 3.437 & 27.440 & 37.669 \\
One-step self-etch adhesive (2) & 15.358 & 2.602 & 11.659 & 20.748 \\
Pre-etching of self-etch adhesive (3) & 25.404 & 4.256 & 19.150 & 32.592 \\
\hline
\end{tabular}

The group (1) was treated with etch and rinse approach (Adper ${ }^{\mathrm{TM}}$ Single Bond 2), the group (2) was treated with self-etch approach (Single bond universal adhesive) and the group (3) was treated with selfetch approach with pre-etching with 35\% phosphoric acid for $5 \mathrm{~s}$. Prior to light curing of the bonding resin on each specimen, two hollow vinyl tubes with an internal diameter of $0.9 \mathrm{~mm}$ and $1 \mathrm{~mm}$ height were placed on the treated surfaces. After light curing with a halogen light-curing unit with $400 \mathrm{~mW} / \mathrm{cm}^{2}$ of light intensity for $10 \mathrm{~s}$, the vinyl tube received a micro-hybrid composite, they were carefully inserted into the tubing lumens, and then light cured for 20 seconds. The specimens were then stored in water at $37^{\circ} \mathrm{C}$ for $24 \mathrm{hrs}$, after removal from water, the tube around composite cylinders was removed then subjected to micro-shear bond strength testing, the load required for de-bonding was recorded in Newton and divided by bonding area to express the bond strength in MPa.

\section{Results}

Data in table (2) shows the descriptive statistics and test of significance for the effect of adhesive system on micro-shear bond strength in ( $\mathrm{MPa})$ to enamel. The mean micro-shear bond strength of two-step etch 
and rinse adhesive system (1) was the highest $31.307 \pm 3.437 \mathrm{~N}$, followed by preetching of the self-etch adhesive system (3) $25.404 \pm 4.256 \mathrm{~N}$, followed by one-step selfetch adhesive system (2) which was the lowest $15.358 \pm 2.602 \mathrm{~N}$. There was a significant difference between the three groups.

\section{Discussion}

In the current study, the micro-shear bond strength of one self-etching and one etch and rinse adhesive systems to enamel were carried-out. The results of the present study showed that the "etch and rinse" approach produced higher bond strength to human enamel, which was statistically different from both "self-etch" approach and "pre-etching of the self-etch approach". These results are in agreement with the data obtained by Erickson et al, $(2009)^{(4)}$, and Moura et al, (2009) ${ }^{(5)}$. The high bond strength recorded in this study of etch and rinse adhesive to enamel may be attributed to the ability of dental adhesive resins to penetrate into the subsurface micro-porosities created in etched enamel which was initially reported by Buonocore et al, (1968) $)^{(6)}$. The enhancement in surface area and energy that was associated with the altered topography as well as the underlying layer of hybrid-like enamel tissue has been accredited with the strong resinenamel bond. Although the self-etching adhesives have demonstrated comparable bonding capabilities to dentin as conventional systems, different studies suggests that the bond to enamel is inferior ${ }^{(7)}$. The action of self-etching systems on enamel has been reported to produce ill-defined surface structures. Although the $\mathrm{pH}$ of the self-etching adhesive system used in this study was around 1 (strong), its bond strength to enamel was lower than expected. This may be due to: the low initial $\mathrm{pH}$ of more acidic systems appear to dra- matically weaken the bonding performance ${ }^{(8)}$, via the presence of solvents within the polymer, which render the adhesive layer thinner and may weaken the polymer formed, thus compromising their bond strength to enamel. The bond strength results of this study showed that pre-etching prior to application of Single-BondUniversal increased the bond strengths: this was in accordance with the findings of Nazari et al, $2012^{(9)}$. The phosphoric acid etching prior to the adhesive application allows a more efficient and durable bond. The demineralization process selectively dissolves the enamel rods, creating microporosities, which are readily penetrated, even by ordinary hydrophobic bonding agents, by capillary attraction. Upon polymerization, this micromechanical interlocking of tiny resin tags within the acid-etched enamel surface still provides the best achievable bond to the dental substrate.

\section{References}

1. Loguercio AD, Reis A, Bortoli G, Patzlaft R, Kenshima S, Rodrigues Filho LE, Accorinte Mde L, Van Dijken JW. Influence of adhesive systems on interfacial dentin gap formation in-vitro. Oper Dent. 2006; 31 (4): 431-441.

2. Van Meerbeek B, De Munck J, Yoshida Y, Inoue S, Vargas M, Vijay P, Van Landuyt K, Lambrechts P, Vanherle G. Buonocore memorial lecture. Adhesion to enamel and dentin: current status and future challenges. Oper Dent. 2003; 28(3):215-235.

3. McDonough WG, Antonucci JM, He J, Shimada Y, Chiang MY, Schumacher GE, Schultheisz CR. A microshear test to measure bond strengths of dentinpolymer interfaces. Biomaterials. 2002; 23 (17): 3603-3608.

4. Erickson RL, Barkmeier WW, Latta MA. The role of etching in bonding to enamel: $A$ comparison of self-etching and etch-andrinse adhesive systems. Dent Mater. 2009; 25 (11): 1459-1467.

5. Moura SK, Reis A, Pelizzaro A, Dal-Bianco 
K, Loguercio AD, Chavez VE, Grande RH. Bond strength and morphology of enamel using self-etching adhesive systems with different acidities. J Appl Oral Sci. 2009; 17 (4): 315-325.

6. Buonocore MG, Matsui A, Gweinn-ett AJ. Penetration of resin dental materials into enamel surfaces with reference to bonding. Arch Oral Biol. 1968; 13 (1): 61-70.

7. Carvalho RM, Fernandes CA, Vilanu-eva $R$, Wang L, Pashley DH. Tensile strength of human dentin as a function of tubule orientation and density. J Adhes Dent. 2001; 3 (4):309-314.

8. Sanares $A M$, Itthagarun A, King NM, Tay FR, Pashley DH. Adverse surface interactions between one-bottle light-cured adhesives and chemical-cured composites. Dent Mater. 2001; 17 (6): 542-556.

9. Nazari A, Shimada Y, Sadr A, Tagami J. Preetching vs. grinding in promotion of adhesion to intact enamel using self-etch adhesives. Dent Mater. 2012; 31 (3): 394-400. 